\title{
Determining the type locality and collector of Nylander's South African lichens
}

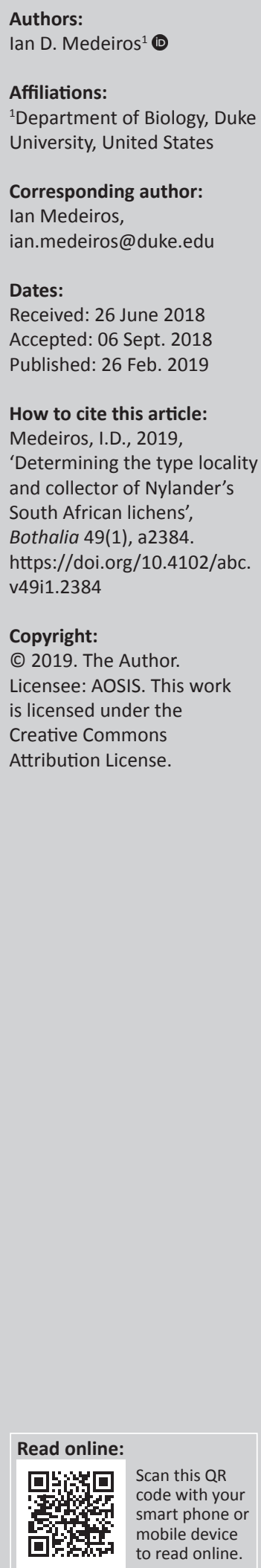

Background: In 1868, Nylander described 15 new lichen taxa from collections made near Durban, South Africa. The locality was not specified and the collector was identified only as 'Miss Armstrong'.

Objectives: To identify the collector and type locality of Nylander's species.

Method: Scientific literature, maps, letters, notebooks and genealogical sources were consulted to reconstruct the provenance of the specimens.

Results: 'Miss Armstrong' was likely Olivia Armstrong; she collected in the Karkloof area of the KwaZulu-Natal Midlands.

Conclusion: This investigation facilitates future work to determine whether the species described and reported by Nylander are still extant in the same locality.

\section{Introduction}

In 1868, Finnish taxonomist William Nylander published a short article on lichens collected from 'Port-Natal' (Nylander 1868). This paper identified 84 species and infraspecific taxa, many of which had not previously been reported from southern Africa and 15 of which were new to science. Most of these new species have neither been recorded since their original description nor given a modern taxonomic assessment (Table 1). Nylander's paper was one of the earliest publications to discuss lichens from eastern South Africa (Doidge 1950) and represents his most substantial contribution to South African botany.

Nylander was one of the pre-eminent lichenologists of his day; like many other prolific European and American taxonomists of that era, he did little fieldwork and relied on collectors around the world who sent samples for him to identify and describe (Ahti 1990). Nylander's (1868) article includes a sparse provenance for the 'Port-Natal' collections. The specimens came to him by way of the Irish lichenologist Theobald Jones, who received them from a 'Mr Mackenzie'. Mackenzie, in turn, obtained the lichens from a collector identified only as 'Miss Armstrong'. Nylander provides no other information about the collector or collection locality.

Subsequent writers have done no better at naming Miss Armstrong. The next reference to her in the scientific literature lists Miss Armstrong and her father ('Dr Armstrong') as collectors with specimens from South Africa and New Zealand in the Kew herbarium (Jackson 1901). In a 1950 historical account of research on fungi in South Africa, Ethel Doidge writes that 'About Miss Armstrong, an early collector of lichens, no details have been found, although several families of that name were resident in Natal in the second half of the 19th century' (Doidge 1950:29). Apparently, no details were uncovered in the following decades, because a 1974 article simply lists 'Dr and Miss Armstrong' among 'other Natalians who contributed collections of Natal plants to overseas herbaria' (Bayer 1974:46).

Both editions of Botanical Exploration of Southern Africa include Miss Armstrong and her father. Under the heading 'Armstrong, Dr and Miss', the first edition mentions the collections sent to Kew and Nylander (Gunn \& Codd 1981). The second edition provides additional biographical details about Dr Armstrong, but Miss Armstrong is left out of the heading, appearing only in the last line of her father's biography: 'One of his daughters collected with him, but it is apparently not known who' (Glen \& Germishuizen 2010:80). The reason for this change is unclear; the one additional reference cited in the second edition says only that 'Dr. Armstrong and one of his daughters are numbered among the early collectors of Natal plants' (Spencer 1983:72). 
TABLE 1: New species described by Nylander (1868).

\begin{tabular}{|c|c|c|c|}
\hline Species & Holotype $\uparrow$ & $\begin{array}{l}\text { Later collected in } \\
\text { South Africa? } \$\end{array}$ & Current status \\
\hline Chiodecton natalense Nyl. & H-NYL & Yes & A good species; still classified in Chiodecton (Ertz et al. 2015) \\
\hline Collema redundans Nyl. & DBN & No & Also reported from Brazil (Degelius 1986); no modern taxonomic assessment \\
\hline Graphis intexta Nyl. & H-NYL & No & Lücking et al. (2015) provisionally classify as a Diorygma species; no modern taxonomic assessment \\
\hline Lecanora sophodes var. atroalbida Nyl. & DBN & Yes & $\equiv$ Rinodina atroalbida (Nyl.) C.W. Dodge; no modern taxonomic assessment (Mayrhoffer 1984) \\
\hline Lecidea anteposita Nyl. & DBN & No & No modern taxonomic assessment \\
\hline Lecidea armstrongiae $\mathrm{Nyl} . \S$ & DBN & No & $\equiv$ Biatorella armstrongiae (Nyl.) Zahlbr.; no modern taxonomic assessment \\
\hline Lecidea inconsequens $\mathrm{Nyl}$. & H-NYL & No & 三 Bacida inconsequens (Nyl.) Zahlbr.; no modern taxonomic assessment \\
\hline Lecidea inconveniens Nyl. & H-NYL & No & $\equiv$ Bacida inconveniens (Nyl.) Zahlbr.; no modern taxonomic assessment \\
\hline Lecidea intermixta f. cyanocentra Nyl. & H-NYL & No & $\begin{array}{l}\text { L. intermixta s.str. was transferred to Megalaria (Kalb 2007), but f. cyanocentra was not included in } \\
\text { the synonymy }\end{array}$ \\
\hline Lecidea fuscorubescens $\mathrm{Nyl}$. & H-NYL & No & Report from Trinidad (Vainio 1923) is suspect; no modern taxonomic assessment \\
\hline Lecidea subinquinans $\mathrm{Nyl}$. & DBN & No & $\begin{array}{l}\text { No modern taxonomic assessment; Nylander's (1868) description indicates that this is a } \\
\text { lichenicolous fungus }\end{array}$ \\
\hline Leptogium chloromeloides Nyl. & DBN & Yes & Accepted by Kitaura et al. (2013) without examination of the type specimen \\
\hline Pyrenopsis mackenziei Nyl. & H-NYL & No & No modern taxonomic assessment \\
\hline Opegrapha diagraphoides Nyl. & H-NYL & No & Synonym of the widespread palaeotropical O. simplicior (Nyl.) Nyl. (Ertz 2009) \\
\hline
\end{tabular}

$\uparrow$, The Nylander herbarium (H-NYL) lacks the original material examined by Nylander for several of these species. Because these names are all clearly based on the collections sent to Nylander by Jones, and Nylander is known to have often returned the bulk of examined specimens to their sender (Ahti 1990), the original specimens of these species at Dublin (DBN) should be regarded as the holotypes per Article 9, Note 1, of the International Code of Nomenclature (ICN): 'If the author used only one specimen or illustration, either cited or uncited, when preparing the account of the new taxon, it must be accepted as the holotype' (Turland et al. 2018:9).

$\$$ Whether or not a taxon has been subsequently collected in South Africa was assessed with Doidge (1950), Fryday (2015) and GBIF Secretariat (2017).

$\S$, These names have traditionally been cited with T.A. Jones as the authority, but there is no indication within the paper itself or in correspondence between Jones and Nylander that Jones provided the descriptions - only that he suggested the epithets. Thus, the correct authority is 'Nylander' or (less preferably, but still permissible) 'Jones ex Nylander' per Article 46.5 of the ICN: 'A name of a new taxon is attributed to the author(s) of the publication in which it appears when the name was ascribed to a different author or different authors but the validating description or diagnosis was neither ascribed to nor unequivocally associated with that author or those authors' (Turland et al. 2018:115-116).

I, A specimen at the Herbarium Genevense (G) is erroneously annotated as a type of Leptogium chloromeloides; the specimen is labelled 'Natal: L.M. Wood 326, ex hb. Kew 1886'.

Most recently, Catherine Horwood (2012) notes in Women and Their Gardens that:

A collection of lichens from Natal and plants from New Zealand were received at Kew in 1867, having been gathered by a Miss Armstrong three years earlier; who Miss Armstrong was and why she was traveling in the southern hemisphere are not recorded. (pp. 24-25)

This comment is almost certainly based on Jackson (1901).

The initial impetus for the present article was to identify Miss Armstrong and investigate her activities as a botanical collector. However, determining Miss Armstrong's identity also entailed locating the probable area in which she collected. Resolving collection localities from vague or incorrect descriptions in the original literature requires investigation of letters, notebooks and similar sources - the same sort of work necessary for a biographical study. This kind of investigation is particularly important when a species is only known from its type locality - as is the case for a number of the species involved here - because relocating that locality is a first step towards determining the species' current status.

\section{Methods}

The literature cited in the introduction provided a starting point for research into the Armstrong family. A search for additional information on the Armstrong family was conducted in the digitised Pietermaritzburg Archives Repository. Archives associated with Theobald Jones (National Botanic Gardens of Ireland, Glasnevin) and William Nylander (National Library of Finland) were consulted to find letters and notebooks that mentioned Miss Armstrong's collections. Online specimen databases and correspondence with curatorial staff at relevant herbaria (K, H-NYL and DBN) were used to locate specimens.

\section{Results}

The literature and archival search sheds light on the cast of characters involved in this taxonomic story. A letter from Jones to Nylander (Jones 1866a) explains that 'Mr Mackenzie' acquired the lichens at the request of Jones' cousin Robert Garden, a British soldier and naturalist who was stationed in Pietermaritzburg during the 1850s (Glen \& Germishuizen 2010). That letter also alleges that the lichens were collected primarily by a 'Mr Trotter', whose farm was close to Mackenzie's. However, a second letter from Jones to Nylander (Jones 1866b) clarifies that Trotter played no role in the collecting and that it was in fact a 'Miss Armstrong' who collected most of the specimens, with Mackenzie collecting some others.

Who, then, was Miss Armstrong - the namesake for the species Lecidea armstrongiae described in Nylander's paper? Spencer (1983) provides some useful details about her family. We know that her father was Dr William Armstrong, who had 11 children, including 6 daughters, with his wife Mary Ann Stevens. The oldest daughter, Mary Jane, died in 1856 before the family left England for South Africa. The remaining daughters were Olivia Wolfenden (b. about 1845), Mary Kathleen (b. about 1850), Ann Kathleen (b. 1854), Amy Jane (b. 1859) and Edith (b. 1862). Miss Armstrong's lichen specimens reached Europe in two shipments in mid- and late 1866 (Jones 1866a, 1866b, 1866c) and were probably collected earlier that year. The three youngest daughters (aged 12, 7 and 4) would have been too young to be collecting lichen specimens for taxonomic 
study, whereas Mary Kathleen (ca. 16 years old) and Olivia (ca. 21 years old) are both plausible candidates.

Jones (1866b) notes that 'Miss Armstrong is a Fern Collector and ... also professes some knowledge of Botany'. Given the ages of Olivia and Mary Kathleen, it seems somewhat more likely that Olivia was the one with botanical knowledge, although this is far from certain. Additional circumstantial evidence comes from material published several decades later. Olivia Armstrong married James Thomas Ball in 1872 (Spencer 1983), and, in 1922, Olivia Wolfenden Ball was listed as a member of the South African Association for the Advancement of Science (Anonymous 1922). Although there is no explicit proof that Olivia, rather than Mary Kathleen, was Nylander's 'Miss Armstrong', her age at the time the collections were made and her later interest in science suggest that she is the more probable collector. Olivia Armstrong died on 05 May 1934 in Durban; accompanying the death notice is extensive documentation of a dispute over her will, which unfortunately gives no details about specific possessions that might indicate botanical interests (Pietermaritzburg Archives Repository 1934).

The tentative identification of Olivia Wolfenden Armstrong as Nylander's 'Miss Armstrong' also clarifies the locality where the lichens were collected. Rather than being from the Durban area (as the title of Nylander's paper suggests), the specimens are likely from the KwaZulu-Natal Midlands, specifically the Karkloof region north of Pietermaritzburg where the Armstrong family lived (Spencer 1983; Figure 1). That this is the most plausible collection locality is reinforced by the mention in Jones' letters of other individuals Mackenzie and Trotter - who lived on farms close to the Armstrong family's Rodeborough (Jones 1866a, 1866b; Surveyor General's Office 1904). The 'Mr Mackenzie' who served as an intermediary in Robert Garden's effort to acquire lichen specimens for Jones was almost certainly a William Mackenzie who lived on a nearby farm called Cramond (Shaw 1990).

Early in this investigation, it was discovered that the bulk of Miss Armstrong's specimens, including several holotypes, which Nylander did not keep in Helsinki, are housed at the herbarium of the National Botanic Garden, Glasnevin, in Ireland (DBN). The specimens are fragmentary as a consequence of their manner of collection and initial transit from South Africa; Jones (1866a) notes that the first set of specimens he received 'having been crushed into a small box and not covered or protected, suffered greatly in the transit'. Furthermore, Jones writes that the specimens of the second set:

were carefully attended to and they have arrived in good Condition but the other Instruction as to the size of the specimens has been disregarded - in fact they are all mere fragments, as if a specimen had been broken up and each particle put into a separate paper. (1866c)

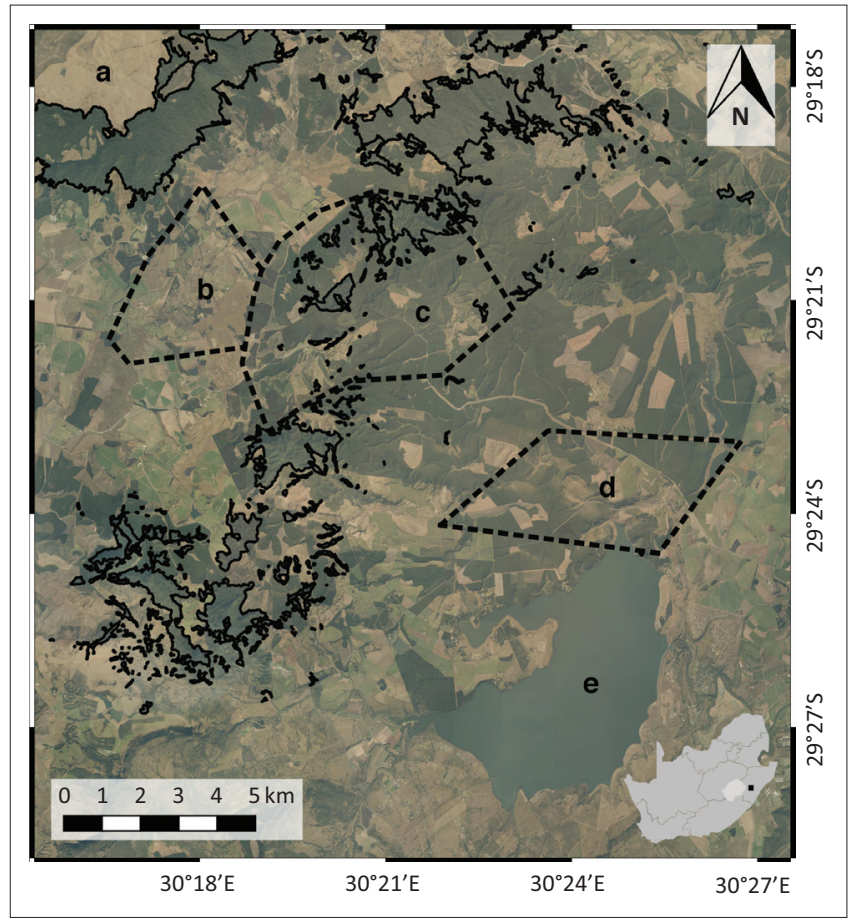

FIGURE 1: The probable type locality of species described by Nylander (1868). A map (Surveyor General's Office 1904) showing the location of the Armstrong farm - called, at various times, Rod(e)borough, RoodeSpruit, and Amberly (Spencer 1983) - indicates that the farm occupied the upper reaches of a creek draining into the Umgeni River. Dashed lines indicate the approximate boundaries of relevant farms circa 1904. Solid black lines indicate present-day extent of forest cover (South African National Biodiversity Institute 2012). (a) Karkloof Nature Reserve (present day). (b) Farm occupied by Trotter family.

(c) Farm occupied by Armstrong family. (d) Farm occupied by Mackenzie family. (e) Reservoir of Albert Falls Dam (present day).

\section{Discussion}

South Africa hosts a diverse lichen biota which is underexplored compared to other groups of organisms in the country (Fryday 2015). In addition to a large number of species, which likely remain undescribed, there are many taxa historically described from the country that are only known from a single collection (Doidge 1950; Fryday 2015). Studies such as the present investigation, which has identified the type locality for about a dozen such species and located the original herbarium vouchers used for the descriptions, are an essential first step in re-evaluating these taxa.

The newly identified locality for the collections treated by Nylander (1868) suggests that the specimens were collected in Southern Mistbelt Forest and Midlands Mistbelt Grassland (Mucina \& Rutherford 2006), not in coastal habitats as might be implied by Nylander's original, vague description. Re-examination of the original specimens at DBN may be sufficient to resolve the taxonomic status of some of Nylander's species (Table 1), but new collections and molecular investigation will probably be necessary for species with poor type specimens or which are morphologically close to species described from elsewhere in the world. The presence of this type material in Dublin has apparently not been previously recognised and the absence of certain holotypes from Nylander's herbarium (H-NYL) has stymied at least one attempt to revise a taxon 
described by Nylander from this collection (Mayrhoffer 1984). Because there are still forest patches in the collection locality (Figure 1), an attempt to rediscover these species in nature can begin precisely where they were originally found.

No record could be found of an 1867 visit to New Zealand by Miss Armstrong or her father. It seems likely that a different collector with the surname Armstrong was active in New Zealand and that Jackson (1901) erred in linking the New Zealand and South Africa collections. This hypothesis is supported by the fact that the Kew herbarium houses a number of New Zealand vascular plant specimens collected in 1867 by Joseph B. Armstrong (Herriott 1919; Appendix 1), an individual not listed by Jackson (1901). Kew specimens also confirm that Dr Armstrong (and possibly Olivia as well) did collect South African plants: at least two specimens collected by someone with the surname Armstrong have the locality 'Rodeborough, Natal' - one name used for Dr Armstrong's farm (Spencer 1983).

\section{Conclusion}

No other specimens collected by Olivia Armstrong appear in the lichenological literature, suggesting that lichens did not become a major interest for her after her 1866 foray. But Olivia Armstrong and William Mackenzie made an important early contribution to lichen taxonomy in South Africa, providing the source material for dozens of new records for southern Africa and 15 taxa new to science. Some of these species have never been reassessed in light of modern lichen taxonomy, meaning that the specimens Olivia Armstrong collected in the 1860s are still relevant to biodiversity research in South Africa today.

\section{Acknowledgements}

Orvo Vitikainen and Leena Myllys (H), Howard Fox (DBN), Craig Brough (K) and Alan Fryday (MSC) are warmly thanked for their help in locating specimens and documents, and Nishanta Rajakaruna and Stefan Siebert are thanked for faciliatating the author's research on South African lichens. Members of the Systematics Discussion Group at Duke University provided useful feedback on an early draft of this article, and two anonymous reviewers are thanked for comments which improved the manuscript.

\section{Competing interests}

The author declares that he has no financial or personal relationships that may have inappropriately influenced him in writing this article.

\section{Funding}

The author is supported by a first-year $\mathrm{PhD}$ fellowship from the Duke University Graduate School and a Graduate Research Fellowship from the US National Science Foundation.

\section{References}

Ahti, T., 1990, 'Introduction to collected lichenological papers of William Nylander '(1822-1899)', in T. Ahti (ed.), William Nylander's collected lichenological papers, vol. I, pp. viii-xxiv, I. J. Cramer, Berlin.

Anonymous, 1922, 'List of members of the South African Association for the Advancement of Science', South African Journal of Science 18, i-xxiv.

Bayer, A.W., 1974, 'Discovering the Natal flora', Natalia 4, 42-48.

Degelius, G., 1986, 'Studies in the lichen family Collemataceae V. Notes on some interesting Collema species', Nordic Journal of Botany 6, 345-349. https://doi. org/10.1111/j.1756-1051.1986.tb00888.x

Doidge, E.M., 1950, 'The South African fungi and lichens to the end of 1945', Bothalia 5, 1-1094.

Ertz, D., 2009, 'Revision of the corticolous Opegrapha species from the Paleotropics', Bibliotheca Lichenologica 102, 1-176.

Ertz, D., Tehler, A., Irestedt, M., Frisch, A., Thor, G. \& van den Boom, P., 2015, 'A largescale phylogenetic revision of Roccellaceae (Arthoniales) reveals eight new genera', Fungal Diversity 70(1), 31-53. https://doi.org/10.1007/s13225-014-0286-5

Fryday, A.M., 2015, 'A new checklist of lichenised, lichenicolous and allied fungi reported from South Africa', Bothalia 45(1), Art. \#148, 1-4. http://doi.org/10.4102/ abc.v45i1.148

GBIF Secretariat, 2017, 'GBIF Backbone Taxonomy', Checklist Dataset, viewed 26 March 2018, from https://doi.org/10.15468/39omei accessed via GBIF.org.

Glen, H.F. \& Germishuizen, G. (compilers), 2010, Botanical exploration of southern Africa, 2nd edn., (Strelitzia 26), South African National Biodiversity Institute, Pretoria.

Gunn, M. \& Codd, L.E., 1981, Botanical exploration of southern Africa: An illustrated history of early botanical literature. Biographical accounts of the leading plant collectors and their activities in southern Africa from the days of the East India Company until modern times, A.A. Balkema, Cape Town.

Herriott, E.M., 1919, 'A history of Hagley Park, Christchurch, with special reference to its botany', Transactions and Proceedings of the Royal Society of New Zealand 51, 427-47.

Horwood, C., 2012, Women and their gardens: A history from the Elizabethan era to today, Chicago Review Press, Chicago.

Jackson, B.D., 1901, 'A list of the collectors whose plants are in the herbarium of the Royal Botanic Gardens, Kew, to 31st December, 1899', Bulletin of Miscellaneous Information (Royal Botanic Gardens, Kew), 169/171, 1-80.

Jones, T., 1866a, Letter to William Nylander, [May?] 1866, Nylander correspondence, National Library of Finland (Helsinki).

Jones, T., 1866b, Letter to William Nylander, 3 September 1866, Nylander correspondence, National Library of Finland (Helsinki).

Jones, T., 1866c, Letter to William Nylander, December 1866, Nylander correspondence, National Library of Finland (Helsinki).

Kalb, K., 2007, 'New or otherwise interesting lichens. III', Bibliotheca Lichenologica 95 297-316.

Kitaura, M.J., 2012, 'Estudos Taxonômicos De Leptogium (Ach.) S.f. Gray (Collemataceae, Fungos Liquenizados)', PhD thesis, Instituto De Biociências, Universidade Estadual Paulista, Botucatu, Brazil.

Kitaura, M.J., Marcelli, M.P., Hora, B.R. \& Jungbluth, P., 2013, 'A new non-isidiate Leptogium species with transverse septate ascospores from Southeastern Brazil', Mycosphere 4, 986-992. https://doi.org/10.5943/mycosphere/4/5/11

Lücking, R., Johnson, M.K., Aptroot, A., Kraichak, E., Lendemer, J.C., Boonpragob, K. et al., 2015, 'One hundred and seventy-five new species of Graphidaceae: Closing the gap or a drop in the bucket?', Phytotaxa 189, 7-38. https://doi.org/10.11646/ phytotaxa.189.1.4

Mayrhoffer, H., 1984, 'Die saxicolen Arten der Flechtengattungen Rinodina und Rinodinella in der alten Welt', Journal of the Hattori Botanical Laboratory 55, 327-493.

Mucina, L. \& Rutherford, M.C. (eds.), 2006, The vegetation of South Africa, Lesotho and Swaziland (Strelitzia 19), South African National Biodiversity Institute, Pretoria.

Nylander, W., 1868, 'Note sur les lichens de Port-Natal', Bulletin de la Société Linnéenne de Normandie ser. 2, 3, 4-15.

Pietermaritzburg Archives Repository, 1934, reference number 21044/1934, death notice for Olivia Wolfenden Ball.

Shaw, C.S., 1990, Stories from the Karkloof Hills, revised and enlarged edition, Shute \& Shooter, Pietermaritzburg.

South African National Biodiversity Institute, 2012, Vegetation Map of South Africa, Lesotho and Swaziland [vector geospatial dataset], Biodiversity GIS, viewed 23 September 2017, from http://bgis.sanbi.org

Spencer, S.O.B., 1983, British Settlers in Natal, 1824-1857: Abbot to Ayres, University of KwaZulu-Natal Press, Pietermaritzburg.

Surveyor General's Office, 1904, Map of the Colony of Natal: Pietermaritzb'g, map Collection of the University of Cape Town Library, viewed 12 March 2018, from www.digitalcollections.lib.uct.ac.za/collection/islandora-19533.

Turland, N.J., Wiersema, J.H., Barrie, F.R., Greuter, W., Hawksworth, D.L., Herendeen P.S., et al. (eds.), 2018, International code of nomenclature for algae, fungi, and plants (Shenzhen Code) adopted by the Nineteenth International Botanical Congress Shenzhen, China, July 2017, Regnum Vegetabile 159, Koeltz Botanical Books, Glashütten, Germany.

Vainio, E.A 1923, 'Lichenes in Insula Trinidad a Professore R. Thaxter Collecti', Proceedings of the American Academy of Arts and Sciences 58(3), 131-147. https://doi.org/10.2307/20025979 


\section{Appendix 1}

\section{Relevant vascular plant specimens at the Kew herbarium}

Note that the search for relevant collections was limited to digitised specimens; not all Kew specimens have been digitised.

Specimens collected by Joseph B. Armstrong in New Zealand in 1867:

K000906750: Junus novae-zealandiae Hook.f.

K001070681, K001070679: Hebe ciliolata (Hook.f.) Cockayne \& Allan

Specimens collected on the Armstrong family farm in 1864:

K000422577: Alberta magna E.Mey.

K000603889: Gleichenia polypodioides (L.) Sm. 